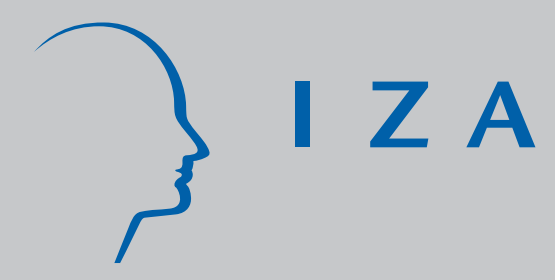

IZA DP No. 2499

The Age of Mass Migration:

Economic and Institutional Determinants

Graziella Bertocchi

Chiara Strozzi

December 2006 


\title{
The Age of Mass Migration: Economic and Institutional Determinants
}

\author{
Graziella Bertocchi \\ Università di Modena e Reggio Emilia, \\ CEPR, CHILD and IZA Bonn \\ Chiara Strozzi \\ Università di Modena e Reggio Emilia
}

Discussion Paper No. 2499

December 2006

\author{
IZA \\ P.O. Box 7240 \\ 53072 Bonn \\ Germany \\ Phone: +49-228-3894-0 \\ Fax: +49-228-3894-180 \\ E-mail: iza@iza.org
}

\begin{abstract}
Any opinions expressed here are those of the author(s) and not those of the institute. Research disseminated by IZA may include views on policy, but the institute itself takes no institutional policy positions.
\end{abstract}

The Institute for the Study of Labor (IZA) in Bonn is a local and virtual international research center and a place of communication between science, politics and business. IZA is an independent nonprofit company supported by Deutsche Post World Net. The center is associated with the University of Bonn and offers a stimulating research environment through its research networks, research support, and visitors and doctoral programs. IZA engages in (i) original and internationally competitive research in all fields of labor economics, (ii) development of policy concepts, and (iii) dissemination of research results and concepts to the interested public.

IZA Discussion Papers often represent preliminary work and are circulated to encourage discussion. Citation of such a paper should account for its provisional character. A revised version may be available directly from the author. 


\section{ABSTRACT \\ The Age of Mass Migration: Economic and Institutional Determinants ${ }^{*}$}

We study the determinants of 19th century mass migration with special attention to the role of institutional factors beside standard economic fundamentals. We find that economic forces associated with income and demographic differentials had a major role in the determination of this historical event, but that the quality of institutions also mattered. We evaluate separately the impact of political institutions linked to democracy and suffrage and of those institutions more specifically targeted at attracting migrants, i.e., citizenship acquisition, land distribution, and public education policies. We find that both sets of institutions contributed to this event, even after controlling for their potential endogeneity through a set of instruments exploiting colonial history and the quality of institutions inherited from the past.

JEL Classification: F22, P16, N33, O15, K40, F54

Keywords: 19th century international migration, institutions, migration policy, democracy, colonial history

Corresponding author:

Graziella Bertocchi

Dipartimento di Economia Politica

Università di Modena e Reggio Emilia

Viale Berengario 51

I-41100 Modena

Italy

E-mail: bertocchi.graziella@unimore.it

\footnotetext{
* We would like to thank S. N. Broadberry, D. DeVoretz, T. J. Hatton, A. M. Mayda, D. Mitra, K.H. O'Rourke, J. G. Williamson, discussants and participants at the North American Summer Meetings of the Econometric Society, the WDI/CEPR Conference on Transition Economics, the Conference on Economic Growth and Distribution, the CEPR Conference on Understanding Productivity Differences Across Sectors, Firms and Countries, AIEL, ENGIME, ESPE, the CEPR Conference on Institutions, Policies and Economic Growth, the CEPR Conference on The Long Run Growth and Development of the World Economy: Measurement and Theory, the Winter Meeting of the Econometric Society, the Workshop on The Economics of Diversity, Migration, and Culture, and seminars in Paris, Padova, Toulouse, Milan, Bologna and IZA, for helpful comments and suggestions on previous drafts. Financial support from the Italian University Ministry and the European Commission is gratefully acknowledged.
} 


\section{Introduction}

A central question in the current economic debate is the importance of institutional factors in determining economic phenomena. In this paper we focus our attention on the determinants of the mass migration waves that took place between the Old and the New World in the period that runs from the middle of the 19th century until World War I. This specific application of the debate on institutions is particularly interesting for several reasons.

First of all, recent research has identified migration as a crucial channel of transmission between institutions and economic outcomes. Acemoglu et al. (2001) link colonial migration to the shaping of institutions themselves, and in turn to subsequent economic development. Engerman and Sokoloff (2002) argue that the evolution of factor endowments and the extent of inequality in New World economies crucially affected the evolution of strategic institutions including migration policy.

Second, for the specific historical episode of 19th century mass migration, while recent research - summarized in Hatton and Williamson (2005a) - has uncovered a number of economic determinants, such as income and demographic differentials, the impact of institutions has not yet been fully investigated. Institutional differentials, such as political and religious factors, have certainly played a decisive role for other migration experiences such as the Jewish Diaspora, or the case of the English Pilgrims. It is therefore crucial to establish if similar considerations may have contributed to the determination of migration decisions also in the case under examination.

Economists and economic historians have already investigated the economic forces that contributed to 19th century emigration from Europe. These studies typically analyze aggregate emigration from a particular source country. Income differentials, usually captured by a measure of the wage gap, had a paramount impact, with richer countries attracting larger inflows. The demographic structure of the population also mattered, because of the higher propensity to migrate of young adults. The degree of industrialization and the consequent reallocation of the labor force away from agriculture had offsetting effects on emigration, since a fall in the agricultural share tended to make labor more mobile, but also to reduce the wage incentive to leave. Network effects established through the stock of previous migrants 
facilitated emigration.

In this paper we study the determinants of mass migration in the 1870-1910 period with special attention to the role of institutions. We first assess the relevance of the standard economic determinants highlighted in the literature on emigration, in particular income differentials, the level of development, the demographic structure of the population, and network effects, Next, we evaluate the impact of institutional factors. To capture the multidimensional nature of institutions, we construct a general index of broad institutional quality based on the level of democracy, the extension of suffrage, the kind of citizenship laws, land distribution policy, public education policy, and an indicator of attitudes toward migration. We also separately investigate the impact of a set of political institutions measuring how a country fares in terms of political rights, not only for migrants but also for its natives, and of a set of migration institutions, i.e., a package of those policies, concerning citizenship acquisition, land distribution and public education, that can make a country attractive to migrants.

The results of our empirical investigation confirm that economic factors played a significant role in determining 19th century mass migration. However, we also find evidence of an influence of institutional factors, with the general index of institutional quality exerting a positive impact on migration. Moreover, we find that both political and migration institutions positively contribute to the effectiveness of our general index, and thus to the level of attractiveness of a country toward migrants. Our results hold after accounting for the potential endogeneity of the institutional variables, through a set of instruments exploiting colonial history and the quality of institutions inherited from the past.

The rest of the paper is organized as follows. In Section 2 we review the related literature. Section 3 presents the basic stylized facts of 19th century mass migration. Section 4 introduces a simple model of international migration. Our data set is described in Section 5. Section 6 illustrates our empirical strategy. Sections 7 presents our results. Section 8 concludes and indicates directions for future research. The Data Appendix collects detailed information about the data employed and illustrates how we compiled our citizenship laws data set. 


\section{Related literature}

This paper represents a contribution to the literature on the economic impact of institutions. Moreover, it adds to research on international migration in a long-term perspective and on the political economy of migration. It is therefore related to several separate branches of the literature.

The first line of research stems from the initial work of North (1981), who established that the social, economic, legal, and political organization of a society is a primary determinant of economic performance. Among recent contributions, the most relevant to our approach are the following. Acemoglu et al. (2001) have estimated the effect of institutions on economic performance by exploiting differences in the mortality rates of European colonizers. Acemoglu and Johnson (2005) progress along this research line by comparing the relative strength of different set of institutions, property rights vs. contracting institutions, for economic outcomes. Persson and Tabellini (2006) decompose the impact of different forms of democracy, i.e., electoral rules and forms of government. Engerman and Sokoloff (2002, 2003) perform a broad comparative analysis of the evolution of institutions in connection with growth in the Americas. Finally, La Porta et al. (1998) start a research line that has uncover the impact of legal origin on a variety of economic issues. Our innovation with respect to this line of research is to select migration as the specific economic outcome for which we test the potential impact of an appropriately selected set of institutions, i.e., political and migration institutions.

The historical experience of 19th century mass migration has been the focus of a number of empirical studies, which have addressed both its causes and its consequences. O'Rourke (1991), Faini and Venturini (1994), Hatton (1995), Taylor and Williamson (1997), Hatton and Williamson (1998, 2005b), and Chiswick and Hatton (2003) examine different aspects of world migration over the past four centuries. More specifically, Goldin (1994), Timmer and Williamson (1998) and Hatton and Williamson (2006a,b) focus on the immigration policies enacted in the 19th century. Recent developments in the debate on immigration are surveyed by Borjas (1994). While most of the available research has analyzed bilateral flows from one source country to one destination, or aggregate migration from a single source country or to 
a single destination, we broaden our perspective to international migration flows. Moreover, we stress their institutional determinants, beside its economic ones.

Finally, we also contribute to the literature that has modeled the political economy of migration policy, following Benhabib (1996), Razin et al. (2002), and Gradstein and Schiff (2006), since the empirical evidence we present corroborates the relevance of migration policy for the decision to migrate. Pritchett (2006) and DeVoretz (2006) discuss the politics of today's labor mobility and migration policies. Recent work on attitudes toward immigrants, by Mayda (2005) and O'Rourke and Sinnott (2005), can also be related to our approach.

\section{The stylized facts of 19th century mass migration}

The period that runs from 1860 until World War I is usually referred to as the age of mass migration. Table 1 presents gross migration rates in the 1870-1910 period for the 14 countries on which our empirical investigation is based. The source is Taylor and Williamson (1997). The table divides countries into two groups: Old World and New World. The Old World consists of Western European countries, which for the period all display negative rates. Most of the European emigrants were young, poor, and unskilled. While Ireland and Britain were the main sources of emigration initially, Germany, Scandinavia and then Southern and Eastern Europe joined in during the subsequent decades. The New World is represented in the table by Australia, Canada and the United States, which were on the receiving side. Out of a much scarcer local population, these countries thus exhibit highly positive rates of immigration. The main destination was North America, followed by South America (which is not included in our sample) and Australasia.

To assess the relative importance of the phenomenon on a wider time span, Table 2 presents a long-term perspective of migration patterns for the 1870-1998 period for a sample of countries similar to ours. The table confirms the magnitude of the early, mass migration waves, with high net flows of migrants for the 1870-1913 period. Migratory movements slow down drastically in the interwar period, to resume in the 1950s, even if it is only after 1974 that they reach a size comparable to the early one, and that yet only in absolute terms. The source of Table 2 is Maddison (2001). While data refer here to net migration, rather than 
gross, this distinction is unimportant for most of the 19th century due to the high cost of returning, even if return migration did become more significant over time.

Going further back, Chiswick and Hatton (2003) and Hatton and Williamson (2005a), among others, have described and quantified the deep differences among the 1860-1913 mass migration and the previous historical waves, i.e., the contracted and coercive migration of the $1600-1790$ period, and the pioneer migration of the $1790-1850$ period. It is only in the middle of the 19th century that migration flows reached the massive size that was then sustained for over fifty years, until the outbreak of World War I. Among the factors that made this surge possible, there are on the one hand the improvement of the technology of transport and communication, and on the other the European famine and revolution.

Economic determinants certainly had a paramount role in 19th century migration, with richer countries attracting larger inflows, and poor countries with a younger population and a larger share in agriculture experiencing heavier emigration, further reinforced by network effects. Indeed the economic and demographic fundamentals of the countries on the sending and the receiving sides were large, and such to justify the massive relocation of workers that we have witnessed.

However, the countries involved also differed in terms of their institutions. Starting with political institutions, in the period under consideration we observe considerable variation both across countries and over time. Receiving countries tended to be far more advanced than Europe, even though North and South America took from the beginning very different routes of development, as reported by Engerman and Sokoloff (2002). At the same time, even within the Old World, during the decades under consideration we observe a positive evolution toward gradual democratization. In particular, between the end of the 19th century and the beginning of the 20th the voting franchise was progressively expanded in Europe, under the pressure of social unrest and the need of modernization. Acemoglu and Robinson (2000) and Lizzeri and Persico (2004), among others, report the stylized facts of this evolution and offer for it a rationale.

Turning to those institutions explicitly targeted to influence migration, it should first of all be noticed that, despite the fact that the period under investigation is usually depicted as an era of unrestricted migration, countries did develop policies toward potential migrants, 
and that these policies were differentiated. Engerman and Sokoloff (2002) provide a historical comparison of the policies enacted in various American countries, which included a variety of provisions regarding access to land and public education, all meant to attract those contemplating relocation. Citizenship policy was also instrumental in enabling migrants to enjoy the benefits of the access to the voting franchise and facilitating integration. Goldin (1994) analyses the evolution of immigration policy in the United States around the turn of the 19th century, with a focus on the debate that eventually led to the restrictive 1917 Literacy Act. Timmer and Williamson (1998) construct an index of immigration policy for five destination countries (Argentina, Australia, Brazil, US, and Canada) in the 1860-1930 period, and study their determinants. Their index is designed to reflect political sentiment and attitudes toward immigration rather than effectiveness of regulation. While attitudes changed significantly for the worse in the period under consideration, as a reaction to the fact that migrants tended to be less skilled, the actual regulation did not change much until World War I, as confirmed by Hatton and Williamson (2006b).

\section{A simple theoretical framework}

In this section we present a simple model to guide our understanding of the potential determinants of international migration. To capture the fact that migration decisions are made over a long horizon, and taking into account also the welfare of the offspring, we consider a dynamic model with bequests where each individual lives for a single period and gives birth to a single child, to whom he leaves a bequest. Each individual has a choice between remaining in his home (or source) country and migrating into a foreign (or destination) country. All individuals are identical and individual preferences are given by

$$
u_{t}=(1-\partial) \log c_{t}+\partial \log b_{t+1}
$$

where $c_{t}$ is the individual level of consumption, $b_{t+1}$ is the bequest for his child, and $\partial$ is a preference parameter, such that $0<\partial<1$. A standard 'joy of giving' bequest motive and a logarithmic functional form are assumed in order to obtain a closed-form solution. Each individual maximizes his utility subject to the following budget constraint: 


$$
c_{t}+b_{t+1} \leq I_{t}
$$

The solution to the individual optimization problem is given by the following consumption and bequest functions:

$$
\begin{gathered}
c_{t}=(1-\partial) I_{t} \\
b_{t+1}=\partial I_{t}
\end{gathered}
$$

Substituting the optimal solution into (1), we can derive the indirect utility function as

$$
v_{t}=\log I_{t}+\xi
$$

where $\xi=(1-\partial) \log (1-\partial)+\partial \log \partial$. It follows that the level of utility an individual can achieve depends on his income level. We can now analyze how the latter is determined.

We assume that individuals are simply endowed with a unit of labor which they supply inelastically to receive a wage income, which depends on location. The migration choice affects individual income as follows. $I_{t}^{H}=w_{t}^{H}$ is the income level if the individual remains in the home country, where $w_{t}^{H}$ is the level of the home wage, while $I_{t}^{F}=w_{t}^{F}-c+\pi$ is the income level if the individual migrates to the foreign country, where $w_{t}^{F}$ is the level of the foreign wage, $c$ is the cost of migration and $\pi$ is the institutional quality of the foreign country. We assume that the level of institutional quality generates direct or indirect material gains, and can therefore be included among the determinants of the income level, and that the level of institutional quality in the home country is normalized at 0 . Note that the income level constrains not only the individual's consumption, but also the bequest he can transfer to his offspring. It follows that an individual decides to migrate if and only if $I_{t}^{F}>I_{t}^{H}$,i.e., if and only if $w_{t}^{F}-c+\pi>w_{t}^{H}$. The gain from migration is positive when the sum of the wage gap, $w_{t}^{F}-w_{t}^{H}$, and the gain from attractive institutions is larger that the cost of migration. In other words, the decision to migrate, $d_{t}$, can be formalized as

$$
d_{t}=w_{t}^{F}-w_{t}^{H}-c+\pi>0
$$

Aggregating over individuals, the migration rate will be higher for countries with higher wages relative to the rest of the world and for countries with more attractive institutions. 
Other factors previously discussed in the literature can be embedded into the model as follows. The agricultural share of labor has been associated with larger emigration, even though in an early stage a large share may prevent emigration by acting as a poverty constraint, while higher manufacturing wages may reverse the effect in later stages. These considerations could be accounted for by assuming that the wage gap in favor of the foreign country is increasing in the agricultural share of the home country. The available literature has also highlighted that the demographic structure of the population matters for migration, since the decision to emigrate is more likely to be taken by young individuals, so that countries with a higher share of young population tend to be associated with larger emigration. Since in our framework the wage rate really captures life-long earning potentials, these considerations could be easily embedded into a multi-period variant of the model through the wage differential. Another potential determinant of migration is the presence of a stock of previous migrants. This network effect can be captured by a reduction of the direct cost $c$.

The quality of institutions $\pi$ is determined by two separate sets of factors, political and migration institutions, which affect the migration decisions through the following channels. The quality of a country's political institutions can be an element of attraction, because of the pecuniary and non-pecuniary costs and benefits associated with democracy. A more democratic environment can improve the quality of the migrants' life per se, because it may be associated with a higher degree of equality, and because it may imply, through the franchise, control over the welfare state and the associated system of taxes and transfers. Turning to the institutions affecting migration more directly, more liberal land and education policies would facilitate relocation and integration. While it is true that public education policies are more likely to affect second generation migrants, in a context where generations are linked through a bequest motive, like ours, the implied material gain is going to affect the decision made by the first generation. Moreover, an easier ascension to citizenship, with the implied full membership in a state, should also increase migration into a country. This applies also to provisions, such a jus soli legislation granting automatic citizenship to second generation migrants, which an individual values because of their impact on his offspring. 


\section{Data}

We use a data set which is based on the sample of 14 countries selected by Taylor and Williamson (1997) for their econometric analysis of international convergence in the 18701910 period. The countries are: Belgium, Denmark, France, Germany, Great Britain, Italy, the Netherlands, Norway, Portugal, Spain, Sweden, Australia, Canada, and the United States. For these countries we assemble a panel with four observations for each country, one for each decade under consideration. In particular, we employ the data collected by Taylor and Williamson (1997) for decade averages of gross migration rates. Moreover, we collect from various sources (details are provided in the Data Appendix) data on the wage gap with respect to the other countries in the sample, the agricultural labor share, and the young adult share of the population. The latter variable is meant to proxy for the demographic structure of the population, while we proxy for network effects using the lagged value of the dependent variable. The resulting data set allows to replicate, with an appropriate adaptation, the analysis conducted by Hatton and Williamson (1998, 2005b) on emigration from 12 European countries in the $1860-1913$ period. ${ }^{1}$

We complete our data set with variables that describe the institutional environment. We start from political institutions, which we capture using two indicators. The first indicator is a standard measure of the degree of democracy represented by the Polity variable from the Polity IV data set. This variable includes information on the institutionalized procedures regarding the transfer of executive power, the extent to which executives are chosen through competitive elections, the opportunity for non-elites to attain executive office, the de facto independence of chief executive, the development of institutional structures for political expression, and the extent to which non-elites are able to access institutional structures for political expression. Our second indicator for the quality of political institutions is a more direct, quantitative measure of the extension of suffrage, which is proxied by the fraction of registered voters over total population.

Next, we select a set of institutions which can be interpreted as parts of a broad migration policy package, and thus are more likely to make a country more attractive to migrants. A

\footnotetext{
${ }^{1}$ Their data include the wage gap, the source country birthrate lagged 20 years, the share of labor in agriculture, and the stock of previous emigrants.
} 
first indicator focuses on the kind of laws that regulated ascension to citizenship. As a proxy for this indicator, we employ citizenship laws at birth at the beginning of each decade for each country, distinguishing between legislations based on jus soli (i.e., by birth place) and jus sanguinis (i.e., by descent). Therefore, this variable is defined by a dummy taking the value of 1 if a country applies a jus soli legislation, and 0 if jus sanguinis. Details on this variable, that we collect and codify, can be found in the Data Appendix, Part B. A second indicator of migration institutions is a measure of land distribution policy, proxied with data on land inequality. Since land inequality data are only available at the end of the period under consideration, we therefore assume that policies that facilitated access to land throughout the period must have resulted in more equal land distribution at the end of it. A final indicator in this set is a measure of public education policy aimed at capturing to what degree countries adopted liberal policies toward public schools. We proxy this indicator taking primary and secondary school enrollment per capita.

We also include in our data set the index of migration policy attitudes constructed by Timmer and Williamson (1998) for five immigration countries, three of which - Australia, Canada and the United States - are in our set. A positive score indicates a pro-immigration, and a negative score an anti-immigration attitude. We assign a zero score to our emigration countries, which did not develop migration policies in those days. To be noticed is that information on citizenship laws is not included in the Timmer and Williamson (1998) migration policy index. ${ }^{2}$ Therefore, the two indicators do not overlap and each retains independent relevance. ${ }^{3}$

To come up with a single measure of institutions, we construct a general index of institutional quality based on the six variables described above. Our index has the advantage of summarizing complex, multi-dimensional issues. Its Cronbach's alpha is 0.60. We also decompose our general index into several dimensions, in the effort to extract from our indicators different basic packages of institutional characteristics. By applying factor analysis to

\footnotetext{
${ }^{2}$ Those three countries which are also in our data set all adopt a jus soli legislation in the entire relevant period.

${ }^{3} \mathrm{~A}$ more open citizenship policy could also be related to democracy, since one of the benefits of citizenship comes from the ability to vote. However, in practice a democratic country could well adopt a jus sanguinis policy, while there are also historical examples of jus soli autocracies.
} 
the data set, we discover that our variables can be explained by three factors, according to a pattern that confirms our previous intuition. ${ }^{4}$ A first factor is common to the two indicators we selected for political institutions, i.e., the variables democracy and suffrage. The Cronbach's alpha of the resulting index is 0.76. A second factor is common to the three indicators that are designed to describe migration institutions, i.e., citizenship laws, land distribution policy, and public education policy. ${ }^{5}$ The Cronbach's alpha of this index is 0.70. Finally, factor analysis reveals that the index of attitudes toward migration is mainly correlated with a third factor. Therefore, we gauge its potential impact separately.

A major advantage, in addition to ease of interpretation, of relying on indexes, rather single variables, rests on the fact that data limitations for this historical period make the direct use of the latter highly problematic. By construction, our indexes span a larger set of observations than most individual sources, thus permitting comparisons of institutions across a broader set of countries than would be possible using any single source. ${ }^{6}$

Finally, to complete our data set, we also collect information on additional variables which have been employed in research on the impact of institutions. We include colonial history, as captured by a dummy which takes the value of 1 if a country has been, or still is in the period under consideration, a colony, and legal origin, as captured by a dummy that takes the value of 1 if a country has a common law legal origin, and of 0 if civil law.

Table 3 reports summary statistics for the variables in our sample, including the indexes. The pairwise correlations among our institutional variables and indexes are reported in Table 4. The table shows that democracy and suffrage are highly correlated (0.61), and so are land and education policies (0.66), while in turn citizenship policy is highly correlated with land policy (0.45) but not with the political indicators. Migration attitudes are uncorrelated with the other institutional variables and the political and migration institutions

\footnotetext{
${ }^{4}$ We perform maximum-likelihood factor analysis and find that the retained factors are three. The results are similar if we use instead principal factors.

${ }^{5}$ Note that the correlation of public education policy with the first factor is almost as high as the correlation with the second. We choose to include this variable in the second index because this suits previous economic intuition.

${ }^{6}$ More specifically, in creating the indexes, if an observation is missing for an institutional variable, then the index is created using the remaining information.
} 
indexes. The political and migration institutions indexes are both highly correlated with the general index (0.61 and 0.89 , respectively), while their correlation is positive but insignificant. The (unreported) pairwise correlations between gross migration and our institutional variables can be summarized as follows: there is a significant and positive correlation of migration with democracy (0.53), suffrage (0.60), citizenship laws (0.33), land distribution policy (0.48), public education policy (0.60), while migration and attitudes toward migration are uncorrelated (0.11). Moreover, migration is positively correlated with the wage gap $(0.77)$.

\section{Empirical strategy}

\subsection{Empirical specification}

We apply the intuition coming from theory and we investigate the determinants of international migration using the following empirical specification:

$$
M_{i t}=a_{0}+E_{i t}^{\prime} a_{1}+I_{i t}^{\prime} a_{2}+\varepsilon_{i t}
$$

where $M_{i t}$ is the gross migration rate in country $i$ in period $t$ (with $i=1, \ldots, 1$ and $t=1, \ldots 4$ - each country observation corresponding to each of the four decades included in the period 1870-1910). $E_{i t}$ is a vector including economic variables which have been traditionally used to explain the evolution of migration flows in the age of mass migration: the wage gap, the agricultural share, the share of young population, and lagged migration as a way to capture network effects. $I_{i t}$ is an index reflecting institutional determinants. $\varepsilon_{i t}$ is the error term.

We can now suggest a number of specific hypotheses regarding the potential role of the above mentioned factors, starting with the economic variables. We expect a positive effect on a country's rate of migration for the wage gap. The impact of the agricultural share is potentially ambiguous, as previously discussed in Section 3, but a negative coefficient would signal a negative impact on migration of a low development level. Similarly, the share of young in the population should exert a negative impact by increasing emigration. Moreover, an interaction term between the latter two variables could capture the potential presence 
of non-linearities, due to differential fertility rates in rural and urban contexts. If lagged migration captures important network effects, its coefficient should be positive.

Turning to institutions, since our indexes are designed to capture their quality, we expect a positive coefficient for the general index of institutional quality, as well as for the two sub-indexes capturing political and migration institutions, and for the indicator capturing attitudes toward migration. More specifically, for each variable entering our indexes of institutional quality, we can justify its positive contribution to the overall impact as follows. The level of democracy and the extension of suffrage should both represent factors of attraction for potential migrants, assuming that these factors are actually taken into account. The same can be argued for more generous land distribution and public education policies, for more welcoming attitudes toward migration, and for more inclusive citizenship laws based on the jus soli principle.

The use of our citizenship laws variable as a regressor for migration can be subject to a couple of objections. First, British emigrants were actually in a special position when moving to countries belonging to the British Empire, such as Canada and Australia, since they were dual citizens of both Britain and Empire countries. We do not have information on bilateral flows, but Hatton (1995) estimates that about $54 \%$ of British emigrants in the 1870-1913 period actually went to the United States, while only about $42 \%$ went to Canada, Australia and New Zealand. Therefore this objection, even if taken literally, would affect only a minority of the migrants included in our sample. A second objection may come from the fact that all receiving countries in our sample apply a jus soli legislation. However, this is not invalidating our empirical strategy. Since migration decisions are taken on the basis of all factors involved, in principle a country with a high wage gap could turn out to be an attractive destination even in the absence if a jus soli legislation, or vice versa. Indeed, the period witnessed internal migration within Continental Europe, in particular toward jus sanguinis countries such as Belgium and Germany. Likewise, a jus soli country could be associated with an unappealing earning differential and therefore be discarded as a possible destination. The latter is the case, for example, of jus soli Portugal. 


\subsection{Instrumentation strategy}

When dealing with institutions and their impact on the economic environment, we need to account for their potential endogeneity, due to the fact that these variables may themselves change over time under the influence of the economic environment. To deal with this issue, we use instrumental-variables (IV) regressions, as illustrated below.

It is easier to start our discussion of instrument selection from our indexes for political and migration institutions, taken separately. The potential endogeneity of political institutions with respect to the general level of development has been the subject of a long research line. ${ }^{7}$ Within the present context, political institutions may turn out to be endogenous with respect to migration, since for instance a large pool of relatively poor migrants may push toward political change. To address this issue, we run IV regressions where we instrument political institutions with their initial value, i.e., the level of democracy and the extension of suffrage in the first decade of the sample. The argument is that initial political institutions could affect current political institutions, but should have no direct effect on current migration.

The potential endogeneity of migration institutions with respect to migration is explained by the fact that, in principle, a country could respond to migration in selecting its land, education, and citizenship policy. For instance, a country could add jus soli elements under the pressure of the existing immigrants, or could instead orient its legislation toward jus sanguinis in the presence of a large stock of emigrants. To address this issue, we run IV regressions where we instrument migration institutions with three variables: the initial citizenship laws and education policies (i.e., their value in the first decade), and with the dummy capturing colonization. ${ }^{8}$ While the choice of the first two instruments again reflects the assumption that initial policies can affect current policies, but not current migration, the choice of the colonial dummy comes from a tradition of investigation which has stressed the relevance of colonial heritage for a country's general development level. One possible objection to the use of this instrument is that the possible presence of colonial migration, i.e., those bilateral

\footnotetext{
${ }^{7}$ See, for example, Barro (1999) on the determinants of democracy and Acemoglu et al. (2005) on the impact of democracy on income.

${ }^{8}$ Information on land inequality at the beginning of the sample is not available, therefore we cannot apply an analogous instrumentation strategy for the land policy component.
} 
migration flows occurring between any metropolitan country and its colonies, may invalidate our strategy by violating the exclusion restriction, because of a direct impact of the instrument on the dependent variable. However, international migration in the period under consideration was a more complex phenomenon that what colonial migration patterns could explain. For example, British migrants were directed not just to the British colonies, while a large part of the inflows into British colonies actually came from Continental Europe. As an alternative to the dummy capturing colonization, we also experiment with the dummy capturing legal origin. The two are related through the fact that legal systems are adopted or transplanted through colonial heritage.

Finally, we also control for the endogeneity of the migration attitudes index by instrumenting it with its initial value (i.e., its value during the fist decade of the sample).

To sum up, for each separate set of potentially endogenous institutions we propose a separate set of instruments, in order to disentangle its impact on migration. In addition, we also develop an instrumentation strategy for our general institutional index, by employing a combinations of the above selected instruments.

\section{$7 \quad$ Results}

Table 5 reports our OLS regression results on the determinants of migration in the 18701910 period, when only economic factors are taken into account. In column 1 the coefficient of the wage gap is positive and highly significant, confirming its crucial role as uncovered in previous studies. The agricultural share, which captures the level of development, turns out to display a significant negative impact, induced by large emigration out of the less industrialized countries. The share of the young population, which proxies for the emigration intensive cohort, also has a significantly negative coefficient, as expected. The positive and significant impact of the interaction term between the latter two regressors could be explained by the presence of higher fertility rates in rural contexts. ${ }^{9}$

The relevant literature has stressed the potential endogeneity of the wage gap, because

\footnotetext{
${ }^{9} \mathrm{We}$ also checked directly for non-linear effects of the agricultural share by adding its square to the regression, but the coefficient turned out to be insignificant.
} 
of its gradual reduction due to convergence, which is in turn accelerated by migration. Therefore, for the same basic specification, we also run a regression where the wage gap is replaced by its lagged value. As column 2 shows, the previous conclusions hold and are actually reinforced, even though in the following specifications we prefer to retain the current value of the wage gap to avoid a drastic reduction of our sample size. In column 3 we explore the potential role of the lagged value of the dependent variable, in the effort to assess the importance of network effects. As expected, lagged migration has a positive effect, but it is insignificant, and remains so in combination with a lagged wage gap specification (column 4).

In Table 6 we add our institutional variables to the standard economic regressors which appear in the basic specification (column 1) of Table 5, and again run OLS regressions. We start by adding our general index of institutional quality, which displays a significantly positive coefficient, while the role of the standard regressors is confirmed. We then decompose institutions into separate components. Both the political and the migration institutions indexes display positive and significant coefficients (columns 2 and 3), revealing that both components contribute to the success of the general index. Consistently with Timmer and Williamson (1998), who stress that their migration attitudes index is not meant to capture policy effectiveness, the coefficient of the index is positive but insignificant (column 4), and remains so when this indicator is entered in combinations with the other two indexes, one by one (columns 5 and 6 ). In column 7 and 8 we enter the political and the migration institutions indexes together, with and without migration attitudes, and previous results are confirmed.

Next, we control for the potential endogeneity of institutions in Table 7 by running 2SLS regressions. In Panel A we show the second stages, while in Panel B we show the corresponding first stages. In column 1 we consider our general index, whose positive and significant impact is confirmed when instrumented by the following two sets of instruments: the first is the instrument we select for political institutions (including the initial values of democracy and suffrage), the second is the instrument for migration institutions (including initial citizenship laws and education policy, plus colonial history). The relevance of both sets of instruments is witnessed not only by the significance of their coefficients and the 
value of the $\mathrm{R}$-squared in the first stage regression, but also by the significance of standard tests of instrument relevance. ${ }^{10}$ In column 2 we show that the political institutions index also confirms its positive impact, when appropriately instrumented. In column 3 we run the same exercise for the migration institutions index, and its positive role is still present even though somehow weaker. ${ }^{11}$ In column 4 we instrument migration attitudes with their initial value, and their irrelevance is once again verified. Finally, in column 5 we consider political and migration institutions jointly. The second stage in Panel A shows that the joint significance of the two regressors is preserved even allowing for their potential endogeneity, while the corresponding first stage regressions in Panel B (columns 5a and 5b) show that the set of instruments we select for political institutions has no influence on migration institutions, and vice versa. ${ }^{12}$ Therefore, this multiple instrumentation strategy allows to unbundle the role of the two separate sets of institutions when jointly considered, i.e., it ensures that they do not affect the dependent variable through the same channels. ${ }^{13}$

In all above specifications, we also gauge the possibility to replace the colony dummy with the common law dummy, but the results are not satisfactory.

Overall, we can therefore conclude that international migration in the 1870-1910 period was driven by economic fundamentals but was also influenced by institutions, since a better institutional quality proves to be a significant factor of attraction for migrants. Moreover, we disentangle the effect of political and migration institutions, and show that each exerts a distinct, significant impact. Finally, the potential feedback between the presence of migrants and institutions is not affecting our conclusions, even accounting for multiple sources of endogeneity.

\footnotetext{
${ }^{10}$ The F-test of the joint significance of all instruments is 33.58, the F-test of excluded instruments is 33.69 , and the Anderson canonical correlation LR statistic is 41.23.

${ }^{11}$ The relevance of the instruments is assured by the significance of the coefficients and the value of the $\mathrm{R}$-squared in the first stage regressions, and by the significance of the F-test of the joint significance of all instruments (36.9 for column 2; 43.24 for column 3), the F-test of excluded instruments (24.8 for column 2; 49.77 for column 3) and the Anderson canonical correlation LR statistic (26.58 for column 2; 38.53 for column 3).

${ }^{12}$ Standard tests again confirm the relevance of the instruments.

${ }^{13}$ Acemoglu and Johnson (2005) similarly unbundle the impact of contracting and property rights institutions.
} 
Overall, we can therefore conclude that international migration in the 1870-1910 period was driven by economic fundamentals but was also influenced by institutions, since a better institutional quality proves to be a significant factor of attraction for migrants. Moreover, we disentangle the effect of political and migration institutions, and show that each exerts a distinct, significant impact. Finally, the potential feedback between the presence of migrants and institutions is not affecting our conclusions, even accounting for multiple sources of endogeneity.

\section{Conclusion}

In this paper we have studied the determinants of 19th century mass migration with particular attention to institutional factors that may have interacted with standard economic fundamentals.

We first assess, in an international migration context, the relevance of the economic forces previously highlighted by the literature focusing on the flows of emigration out of Europe. Our findings confirm that economic forces had major determinants of this historical event. The migrants that left Continental Europe for the New World were certainly motivated by material needs and viewed their destination as the land of economic opportunity. However, we have also found evidence that institutions mattered as well, with better institutions being associated with higher rates of migration even in that historical period. These results concern not only the impact of those institutions more specifically targeted at attracting migrants, such as citizenship, land and education policies, but also the impact of political institutions, with more democratic countries with broader suffrage proving to be more desirable destinations, other things equal.

While our attention was confined to the 19th century, our conclusions do carry implications for the current policy debate on international migration and help to understand the implications of today's restrictive policies toward labor mobility and immigration, in a context where the economic pressure to move from poor to rich countries is high and growing. 


\section{DATA APPENDIX}

\section{A) Data definitions and sources}

All data are decade averages of the corresponding annual figures, except when indicated. The reference decades are the four decades in the 1870-1910 period.

Migration: Gross immigration rates. The source is Taylor and Williamson (1997).

Wage Gap: Log of the wage ratio, where the numerator is a country's real wage and the denominator is a world unweighted average of the other countries' real wages. The source is Williamson (1995).

Agricultural Share: Percent work force engaged in agriculture. The source is Banks (2001). Share of Young Population: Ratio between the young (i.e., aged 15-29) population and total population, from Census data. The source is Mitchell (2003). For each decade we take the Census closer to the year ending in 0 . Note the following exceptions: for the Netherlands the age reported is 10-29 (except in 1900), for Spain it is 16-30.

Democracy: Polity variable from Polity IV (2002).

Suffrage: Registered voters over population. The source is Banks (2001).

Land Distribution Policy: Inverse of the Gini coefficient of land holdings in the first available year after 1910 (with the exception of Germany, for which the year is 1907). The source is Frankema (2006).

Public Education Policy: Primary plus secondary school enrollment per capita. The source is Banks (2001).

Citizenship Laws: Dummy for countries that have a jus soli legislation at the beginning of each decade. The sources are Weil (2001), Joppke (1998), Brubaker (1992), and a variety of library sources. More details on this variable are available below (Data Appendix, Part B).

Migration Attitudes: Index of attitudes toward migration compiled by Timmer and Williamson (1998). Missing countries are assigned a zero score. We thank J. G. Williamson for providing these data.

Institutional Quality Index: Includes the variables democracy, suffrage, land distribution policy, public education policy, citizenship laws, and attitudes toward migration. 
Political institutions index: Includes the variables democracy and suffrage.

Migration institutions index: Includes the variables land distribution policy, public education policy, and citizenship laws.

British Colony: Dummy for countries that were at any time British colonies. The source is the "Correlates of War 2 Project" (2004).

Common Law: Dummy for countries with a common law legal origin. The source is La Porta et al. (1999).

\section{B) The citizenship laws variable}

Historical and legal background Each country of the world has developed a system of legal rules that govern the attribution of citizenship, and therefore regulate the inclusion of newcomers. Citizenship is associated with a precise set of rights and duties. It provides benefits such as the right to vote, better employment opportunities, the ability to travel without restrictions, and legal protection in case of criminal charges. There are also costs to citizenship, such as the military draft, renunciation of the original citizenship, and the pecuniary and non pecuniary costs that may be required for naturalization. Therefore, citizenship policy can be viewed as part of broader migration policy package, even though, contrary to other current migration policy measures such as quotas and visa requirements, that respond to short term business fluctuations and/or the outcome of political elections, citizenship laws reforms tend to be the outcome of long-term processes of adaptation often involving constitutional amendments.

Our codification effort focuses on the laws governing citizenship acquisition at birth, which are therefore especially relevant for second-generation immigrants, even though they are part of the migration decision of any parent who cares for his children and their future. These laws originally come from the two broad traditions of common and civil law. The former applies the jus soli principle, according to which citizenship is attributed by birthplace. This implies that the child of an immigrant is a citizen, as long as he is born in the country of immigration. The latter applies the jus sanguinis principle, which attributes citizenship by descent, so that a child inherits citizenship from his parents, independently of where he is born. 
In 18th century Europe jus soli was the dominant criterion, following feudal traditions which linked human beings to the lord who held the land where they were born. The French Revolution broke with this heritage and with the 1804 civil code reintroduced the ancient Roman custom of jus sanguinis, only to reintroduce elements of jus soli in 1889 for military reasons related to the draft. During the 19th century the jus sanguinis principle was adopted throughout Europe and then transplanted to its colonies. On the other hand, the British preserved their jus soli tradition and spread it through their own colonies, starting with the United States where it was later encoded in the Constitution. By the beginning of the 20th century, the process of nation-state formation and the associated codification effort were completed in Continental Europe. At the same time, the revolutionary phase was over in those countries that had been the subject of the earlier colonization era, and 19th century colonization had extended the process of transplantation of legal tradition to the rest of the world. Therefore, by the end of the period of interest, most countries had completed a slow process of adjustment of their legislation regarding citizenship acquisition, in response to a variety of largely exogenous impulses. On the other hand, after World War II, with the decolonization phase and the collapse of the socialist system, citizenship laws have started a process of further adaptation, with a marked acceleration under the pressure of international migration. The evolution of citizenship laws in the 1950-2000 period is investigated by Bertocchi and Strozzi (2006).

Codification We classify the countries in our data set on the basis of the kind of citizenship laws (i.e., jus soli vs. jus sanguinis) in place at the beginning of each decade under consideration. The data set that we obtain for the 1870-1910 period can be described as follows. Within Europe, the jus sanguinis model tends to dominate, but with several exceptions. Britain, as previously mentioned, always remains a jus soli country, and so does Portugal. Scandinavian countries, as well as the Netherlands, are late-comers that embrace the jus sanguinis legislation only towards the end of the 19th century. France, on the other hand, leads the introduction of jus sanguinis but switches to jus soli in 1889. Outside Europe, jus soli dominates not only in the former British colonies, but also in Latin America. Despite their civil law tradition, these latter countries chose jus soli at independence as a way to break with the colonial political order and to prevent the metropoles from making legitimate 
claims on citizens born in the new countries.

To be noticed is that the citizenship laws, colony, and common law dummies - even though potentially interrelated because British colonization is associated with the spread of both the common law legal system and the jus soli citizenship laws - are positively but not perfectly correlated, i.e., they do capture different institutional characteristics (see Table 4). The correlation between the jus soli and the common law dummies is not perfect because some civil law countries were at times associated with jus soli. This is the case of the Scandinavian countries, which adopted jus sanguinis only toward the end of the sample, of France that abandoned jus sanguinis in 1889, and of Portugal which always applied jus soli.

\section{REFERENCES}

Acemoglu, D. and Johnson, S., 2005, Unbundling Institutions, Journal of Political Economy 113, 949-95.

Acemoglu, D. , Johnson, S. and Robinson, J.A., 2001, The Colonial Origins of Comparative Development: An Empirical Investigation, American Economic Review 91, 1369-1401.

Acemoglu, D. , Johnson, S., Robinson, J.A. and Yared, P., 2005, Income and Democracy, CEPR Discussion Paper 5273.

Acemoglu, D. and Robinson, J.A., 2000, Why Did the West Extend the Franchise? Democracy, Inequality, and Growth in Historical Perspective, Quarterly Journal of Economics 115, 1167-1199.

Banks, A., (2001), Cross-National Time Series, 1815-1999, Center for Comparative Political Research, State University of New York, Binghamton.

Barro, R.J., 1999, Determinants of Democracy, Journal of Political Economy 107, Part 2, S158-S183.

Benhabib, J., 1996, On the Political Economy of Migration, European Economic Review 40, $1737-1744$. 
Bertocchi, G. and Strozzi, C., 2006, The Institution of Citizenship: Economic and Institutional Determinants, Centro Luca D’Agliano Working Paper 211.

Borjas, G., 1994, The Economics of Immigration, Journal of Economic Literature 32, 16671717.

Brubaker, R., 1992, Citizenship and Nationhood in France and Germany, Harvard University Press, Cambridge.

Chiswick, B.R. and Hatton, T.J., 2003, International Migration and the Integration of Labor Markets, in Bordo, M., Taylor, A. and Williamson, J.A. (eds.), Globalization in Historical Perspective, 65-119, National Bureau of Economic Research, Cambridge.

Correlates of War 2 Project, 2004, Department of Political Science, The Pennsylvania State University.

DeVoretz, D.J., 2006, Immigration Policy: Methods of Economic Assessment, International Migration Review 40, 390-418.

Engerman, S. and Sokoloff, K.L., 2002, Factor Endowment, Inequality, and Paths of Development Among New World Economies, NBER Working Paper 9259.

Engerman, S. and Sokoloff, K.L., 2003, Institutional and Non-institutional Explanations of Economic Differences, NBER Working Paper 9989.

Faini, R. and Venturini, A., 1994, Italian Emigration in the Prewar Period, in Hatton T. and Williamson J. (eds), Migration and the International Labour Market 1850-1913, 72-90, Routledge, London.

Frankema, E., 2006, The Colonial Origins of Inequality: Exploring the Causes and Consequences of Land Distribution, Groningen Growth and Development Centre Research Memorandum GD-8.

Goldin, C., 1994, The Political Economy of Immigration Restriction in the U.S., 1890 to 1921, in Goldin, C. and Libecap, G.(eds.), The Regulated Economy: A Historical Approach to Political Economy, 223-257, University of Chicago Press, Chicago. 
Gradstein, M. and Schiff, M., 2006, The Political Economy of Social Exclusion with Implications for Immigration Policy, Journal of Population Economics 19, 327-44.

Hatton, T. J., 1995, A Model of U.K. Emigration, 1870-1913, Review of Economics and Statistics 77, 407-415.

Hatton, T.J. and Williamson, J.G., 2006b, International Migration in the Long Run: Positive Selection, Negative Selection and Policy, in Foders, F. and Langhammer, R.J. (eds.), Labor Mobility and the World Economy, Springer, Heidelberg.

Hatton, T.J. and Williamson, J.G., 2005a, Global Migration and the World Economy. Two Centuries of Policy and Performance, MIT Press, Cambridge and London.

Hatton, T.J. and Williamson, J.G., 2005b, What Fundamentals Drive World Migration?, in Borjas, G. and Crisp, J. (eds), Poverty, International Migration and Asylum, PalgraveMacmillan, Hampshire.

Hatton, T.J. and Williamson, J.G., 1998, The Age of Mass Migration: Causes and Economic Impact, Oxford University Press, New York.

Joppke, C. (ed.), 1998, Challenge to the Nation-State: Immigration in Western Europe and the United States, Oxford University Press, Oxford.

La Porta, R., Lopez-de-Silanes, F., Shleifer, A. and Vishny, R.W., 1999, The Quality of Government, Journal of Law, Economics and Organization 15, 222-279.

La Porta, R., Lopes-de-Silanes, F., Shleifer, A. and Vishny, R.W., 1998, Law and Finance, Journal of Political Economy 106, 1113-1155.

Lizzeri, A., and N. Persico, 2004, Why Did the Elites Extend the Suffrage? Democracy and the Scope of Government, with an Application to Britain's 'Age of Reform', Quarterly Journal of Economics 119, 707-765.

Maddison, A., 2001, The World Economy: A Millennial Perspective, OECD, Paris.

Mayda, A. M., 2005, Who is Against Immigration? A Cross-country Investigation of Individual Attitudes Toward Immigrants, Review of Economics and Statistics, forthcoming. 
Mitchell, B.R., 2003, International Historical Statistics, 1750-2002, Vol. I: Europe, Vol. II: The Americas, Vol. III: Africa, Asia \& Oceania, Palgrave-Macmillan, New York.

North, D.C., 1981, Structure and Change in Economic History, Norton, New York.

O’Rourke, K.H., 1991, Did the Great Irish Famine Matter?, Journal of Economic History $51,1-22$.

O'Rourke, K.H. and Sinnott, R., 2005, The Determinants of Individual Attitudes towards Immigration, European Journal of Political Economy, forthcoming.

Persson, T. and Tabellini, G., 2006, Democracy and Development: The Devil in the Details, mimeo.

Polity IV, 2002, Political Regime Characteristics and Transitions, 1800-2002, Center for International Development and Conflict Management, University of Maryland.

Pritchett, L., 2006, Let Their People Come: Breaking the Deadlock in International Labor Mobility, The Brookings Institution Press, Washington.

Razin, A., Sadka, E. and Swagel, P., 2002, Tax Burden and Migration: A Political Economy Theory and Evidence, Journal of Public Economics 85, 167-190.

Taylor, A.M., and Williamson J.G., 1997, Convergence in the Age of Mass Migration, European Review of Economic History 1, 27-63.

Timmer, A. and Williamson, J.G., 1998, Immigration Policy Prior to the Thirties: Labor Markets, Policy Interaction, and Globalization Backlash, Population and Development Review. 24, 739-771.

Weil, P., 2001, Access to Citizenship: A Comparison of Twenty-Five Nationality Laws, in Aleinikoff, T. A. and Klusmeyer, D. (eds.), Citizenship Today: Global Perspectives and Practices, 17-35, Carnegie Endowment for International Peace, Washington.

Williamson, J. G., 1995, The Evolution of Global Labor Markets since 1830: Background Evidence and Hypotheses, Explorations in Economic History 32, 141-196. 
Table 1

Gross migration rates (Migrants/1,000 Population), 1870-1910

\begin{tabular}{|l|c|}
\hline Old World & -4.17 \\
\hline Belgium & -2.12 \\
Denmark & -2.78 \\
France & -0.19 \\
Germany & -1.47 \\
Great Britain & -5.15 \\
Italy & -9.25 \\
Netherlands & -4.18 \\
Norway & -6.55 \\
Portugal & -4.35 \\
Spain & -4.54 \\
Sweden & -5.25 \\
\hline New World & 12.21 \\
\hline Australia & 14.43 \\
Canada & 14.35 \\
United States & 7.86 \\
\hline
\end{tabular}

Source: Taylor and Williamson (1997).

Table 2

Net migration (1,000), 1870-1998

\begin{tabular}{|c|c|c|c|c|}
\hline & $1870-1913$ & $1914-49$ & $1950-73$ & $1974-98$ \\
\hline Old World & $-13,996$ & $-3,662$ & 9,381 & 10,898 \\
\hline France & 890 & -236 & 3,630 & 1,026 \\
Germany & $-2,598$ & -304 & 7,070 & 5,911 \\
Italy & $-4,459$ & $-1,771$ & $-2,139$ & 1,617 \\
Japan & n.a. & 197 & -72 & -179 \\
United Kingdom & $-6,415$ & $-1,405$ & -605 & 737 \\
Others* & $-1,414$ & 54 & 1,425 & 1,607 \\
\hline New World & 17,856 & 7,239 & 12,663 & 21,639 \\
\hline Australia & 885 & 673 & 2033 & 2151 \\
New Zealand & 290 & 138 & 247 & 87 \\
Canada & 861 & 207 & 2,126 & 2,680 \\
United States & 15,820 & 6,221 & 8,257 & 16,721 \\
\hline
\end{tabular}

*Includes Belgium, Netherlands, Norway, Sweden and Switzerland. Source: Maddison, 2001. 
Table 3

Summary statistics

\begin{tabular}{|l|c|c|c|c|c|}
\hline Variable & Observations & Mean & Stand. Dev. & Minimun & Maximum \\
\hline Migration & 53 & -1.510 & 6.983 & -17.970 & 22.640 \\
\hline Wage Gap & 56 & -0.081 & 0.474 & -0.894 & 0.765 \\
\hline Agricultural Share & 51 & 43.912 & 15.255 & 8.945 & 69.730 \\
\hline Share of Young & 55 & 26.291 & 2.664 & 23.338 & 35.846 \\
\hline Democracy & 53 & 1.825 & 5.475 & -7 & 10 \\
\hline Suffrage & 40 & 159.729 & 119.588 & 20.200 & 641.000 \\
\hline Citizenship Laws & 56 & 0.589 & 0.496 & 0 & 1 \\
\hline Land Distribution Policy & 56 & 1.565 & 0.233 & 1.264 & 2.053 \\
\hline Public Education Policy & 49 & 14.010 & 4.293 & 4.424 & 20.502 \\
\hline Migration Attitudes & 56 & 0.092 & 0.647 & -1.682 & 2.250 \\
\hline Institutional Quality Index & 56 & 0.476 & 0.191 & 0.155 & 0.912 \\
\hline Political Institutions Index & 53 & 0.415 & 0.273 & 0 & 1 \\
\hline Migration Institutions Index & 56 & 0.523 & 0.280 & 0.085 & 1 \\
\hline Colony & 56 & 0.286 & 0.456 & 0 & 1 \\
\hline Common Law & 56 & 0.286 & 0.456 & 0 & 1 \\
\hline
\end{tabular}


Table 4

Pairwise correlations among institutional variables

\begin{tabular}{|c|c|c|c|c|c|c|c|c|c|c|c|}
\hline & Democracy & Suffrage & $\begin{array}{c}\text { Citizenship } \\
\text { Laws }\end{array}$ & $\begin{array}{c}\text { Land } \\
\text { Distr. Pol. }\end{array}$ & $\begin{array}{c}\text { Public } \\
\text { Edu. Policy }\end{array}$ & $\begin{array}{c}\text { Migration } \\
\text { Attitudes }\end{array}$ & $\begin{array}{c}\text { Institutional } \\
\text { Quality }\end{array}$ & $\begin{array}{c}\text { Political } \\
\text { Institutions }\end{array}$ & $\begin{array}{l}\text { Migration } \\
\text { Institutions }\end{array}$ & Colony & $\begin{array}{c}\text { Common } \\
\text { Law }\end{array}$ \\
\hline Democracy & 1 & & & & & & & & & & \\
\hline Suffrage & $0.6072 *$ & 1 & & & & & & & & & \\
\hline Citizenship Laws & 0.0672 & 0.0375 & 1 & & & & & & & & \\
\hline Land Distr. Pol. & 0.1490 & -0.0184 & $0.4525^{*}$ & 1 & & & & & & & \\
\hline Public Edu. Pol. & $0.4990^{*}$ & $0.4081 *$ & 0.1946 & $0.6580^{*}$ & 1 & & & & & & \\
\hline \begin{tabular}{|l|} 
Migration Attitud. \\
\end{tabular} & -0.1314 & -0.0625 & 0.1199 & 0.0466 & 0.0246 & 1 & & & & & \\
\hline Institut. Quality & $0.5710^{*}$ & $0.5091 *$ & $0.7047^{*}$ & $0.6768^{*}$ & $0.7297^{*}$ & $0.2812^{*}$ & 1 & & & & \\
\hline Political Institut. & $0.9243 *$ & $0.8356^{*}$ & 0.0781 & 0.1438 & $0.5138^{*}$ & -0.1263 & $0.6042 *$ & 1 & & & \\
\hline Migration Institut. & 0.2355 & 0.1295 & $0.8283^{*}$ & $0.8284 *$ & $0.6623^{*}$ & 0.0872 & $0.8801 *$ & 0.2459 & 1 & & \\
\hline Colony & $0.4510^{*}$ & 0.2952 & $0.4477^{*}$ & $0.3924 *$ & $0.6655^{*}$ & 0.2270 & $0.7238^{*}$ & $0.5082 *$ & $0.5785^{*}$ & 1 & \\
\hline Common Law & $0.6306^{*}$ & 0.3560 * & $0.5280^{*}$ & $0.3449 *$ & $0.5811^{*}$ & 0.2270 & $0.7754 *$ & $0.6290 *$ & $0.5878^{*}$ & $0.6500 *$ & 1 \\
\hline
\end{tabular}

* significant at $5 \%$ 
Table 5

The economic determinants of mass migration

\begin{tabular}{|l|l|l|l|}
\hline \multicolumn{4}{|c|}{ Dependent variable is Migration } \\
\hline & \multicolumn{1}{|c|}{$(1)$} & \multicolumn{1}{c|}{$(2)$} & \multicolumn{1}{c|}{$(3)$} \\
\hline Wage Gap & 14.311 & & 14.298 \\
\hline & {$[7.30]^{* * *}$} & & {$[3.55]^{* * *}$} \\
\hline Agricultural Share & -0.948 & -1.437 & -0.864 \\
\hline & {$[2.20]^{* *}$} & {$[3.82]^{* * *}$} & {$[1.82]^{*}$} \\
\hline Share of Young & -1.534 & -2.295 & -1.452 \\
\hline & {$[2.57]^{* *}$} & {$[4.50]^{* * *}$} & {$[2.17]^{* *}$} \\
\hline Agricult. Sh. X Sh. of Young & 0.041 & 0.062 & 0.039 \\
\hline & {$[2.53]^{* *}$} & {$[4.32]^{* * *}$} & {$[2.08]^{* *}$} \\
\hline Lagged Wage Gap & & 17.041 & \\
\hline & & {$[7.51]^{* * *}$} & \\
\hline Lagged Migration & & & 0.179 \\
\hline & & & {$[0.55]$} \\
\hline Constant & 34.819 & 53.166 & 31.509 \\
\hline & {$[2.15]^{* *}$} & {$[3.80]^{* * *}$} & {$[1.85]^{*}$} \\
\hline Adjust. R2 & 0.66 & 0.78 & 0.74 \\
\hline Observations & 50 & 38 & 37 \\
\hline
\end{tabular}

Robust $t$ statistics in brackets.

$*$ significant at $10 \%$; ** significant at 5\%; *** significant at $1 \%$

Table 6

The impact of institutions on mass migration: OLS

\begin{tabular}{|l|l|l|l|l|l|l|l|l|}
\hline \multicolumn{9}{|c|}{ Dependent variable is Migration } \\
\hline & \multicolumn{1}{|c|}{$(1)$} & \multicolumn{1}{|c|}{$(2)$} & \multicolumn{1}{c|}{$(3)$} & \multicolumn{1}{c|}{$(4)$} & \multicolumn{1}{c|}{$(5)$} & \multicolumn{1}{c|}{$(6)$} & \multicolumn{1}{|c|}{$(7)$} & \multicolumn{1}{c|}{$(8)$} \\
\hline Wage Gap & 10.061 & 11.934 & 12.756 & 14.278 & 11.758 & 12.767 & 8.889 & 8.844 \\
\hline & {$[5.67]^{* * *}$} & {$[5.01]^{* * *}$} & {$[7.25]^{* * *}$} & {$[7.28]^{* * *}$} & {$[4.83]^{* * *}$} & {$[7.12]^{* * *}$} & {$[4.09]^{* * *}$} & {$[3.99]^{* * *}$} \\
\hline Agricultural Share & -1.092 & -1.053 & -1.057 & -0.925 & -1.021 & -1.045 & -1.245 & -1.221 \\
\hline & {$[2.71]^{* * *}$} & {$[2.32]^{* *}$} & {$[2.47]^{* *}$} & {$[2.17]^{* *}$} & {$[2.27]^{* *}$} & {$[2.46]^{* *}$} & {$[2.91]^{* * *}$} & {$[2.87]^{* * *}$} \\
\hline Share of Young & -1.617 & -1.539 & -1.654 & -1.524 & -1.523 & -1.648 & -1.709 & -1.696 \\
\hline & {$[2.94]^{* * *}$} & {$[2.48]^{* *}$} & {$[2.83]^{* * *}$} & {$[2.56]^{* *}$} & {$[2.46]^{* *}$} & {$[2.81]^{* * *}$} & {$[2.96]^{* * *}$} & {$[2.92]^{* * *}$} \\
\hline Agric. Sh. X Sh. of Young & 0.046 & 0.045 & 0.045 & 0.04 & 0.043 & 0.045 & 0.052 & 0.051 \\
\hline & {$[3.06]^{* * *}$} & {$[2.62]^{* *}$} & {$[2.81]^{* * *}$} & {$[2.50]^{* *}$} & {$[2.57]^{* *}$} & {$[2.81]^{* * *}$} & {$[3.22]^{* * *}$} & {$[3.18]^{* * *}$} \\
\hline Institut. Quality Index & 12.799 & & & & & & & \\
\hline & {$[3.29]^{* * *}$} & & & & & & & \\
\hline Political Institut. Index & & 5.374 & & & 5.652 & & 7.305 & 7.439 \\
\hline Migration Institut. Index & & {$[1.83]^{*}$} & & & {$[1.89]^{*}$} & & {$[2.57]^{* *}$} & {$[2.60]^{* *}$} \\
\hline & & & 4.153 & & & 4.086 & 5.849 & 5.723 \\
\hline Migration Attitudes & & & {$[2.14]^{* *}$} & & & {$[2.15]^{* *}$} & {$[3.13]^{* * *}$} & {$[3.14]^{* * *}$} \\
\hline & & & & 0.499 & 0.805 & 0.218 & & 0.508 \\
\hline Constant & & & & {$[0.42]$} & {$[0.65]$} & {$[0.19]$} & & {$[0.40]$} \\
\hline & 30.903 & 33.094 & 35.603 & 34.666 & 32.757 & 35.523 & 33.577 & 33.354 \\
\hline Adjust. R2 & {$[2.10]^{* *}$} & {$[1.96]^{*}$} & {$[2.29]^{* *}$} & {$[2.14]^{* *}$} & {$[1.94]^{*}$} & {$[2.27]^{* *}$} & {$[2.19]^{* *}$} & {$[2.15]^{* *}$} \\
\hline Observations & 0.71 & 0.68 & 0.68 & 0.66 & 0.68 & 0.67 & 0.71 & 0.71 \\
\hline
\end{tabular}

Robust $t$ statistics in brackets

$*$ significant at $10 \% ; * *$ significant at $5 \% ; * * *$ significant at $1 \%$ 
Table 7

The impact of institutions on mass migration: 2SLS

\begin{tabular}{|c|c|c|c|c|c|c|}
\hline \multicolumn{7}{|c|}{ PANEL A: Dependent variable is Migration (Second-stage regressions) } \\
\hline & $(1)$ & $(2)$ & $(3)$ & $(4)$ & $(5)$ & \\
\hline \multirow[t]{2}{*}{ Wage Gap } & 9.663 & 10.758 & 12.312 & 13.914 & 7.894 & \\
\hline & {$[4.44]^{* * *}$} & {$[3.89]^{* * *}$} & {$[6.73]^{* * *}$} & {$[5.07]^{* * *}$} & {$[3.19]^{* * *}$} & \\
\hline \multirow[t]{2}{*}{ Agricultural Share } & -1.12 & -1.115 & -1.088 & -0.666 & -1.295 & \\
\hline & {$[2.77]^{* * *}$} & {$[2.40]^{* *}$} & {$[2.52]^{* *}$} & {$[1.24]$} & {$[2.92]^{* * *}$} & \\
\hline \multirow[t]{2}{*}{ Share of Young } & -1.691 & -1.603 & -1.688 & -1.413 & -1.761 & \\
\hline & {$[3.10]^{* * *}$} & {$[2.54]^{* *}$} & {$[2.88]^{* * *}$} & {$[1.89]^{*}$} & {$[2.91]^{* * *}$} & \\
\hline \multirow[t]{2}{*}{ Agric. Sh. X Sh. of Young } & 0.048 & 0.047 & 0.047 & 0.029 & 0.054 & \\
\hline & {$[3.15]^{* * *}$} & {$[2.71]^{* * *}$} & {$[2.87]^{* * *}$} & {$[1.41]$} & {$[3.23]^{* * *}$} & \\
\hline \multirow[t]{2}{*}{ Institutional Quality Index } & 13.014 & & & & & \\
\hline & {$[2.77]^{* * *}$} & & & & & \\
\hline \multirow[t]{2}{*}{ Political Institutions Index } & & 7.402 & & & 9.193 & \\
\hline & & {$[2.26]^{* *}$} & & & {$[3.19]^{* * *}$} & \\
\hline \multirow[t]{2}{*}{ Migration Institutions Index } & & & 5.338 & & 5.597 & \\
\hline & & & {$[1.70]^{*}$} & & {$[1.99]^{*}$} & \\
\hline \multirow[t]{2}{*}{ Migration Attitudes } & & & & 6.074 & & \\
\hline & & & & {$[1.49]$} & & \\
\hline Adjust. R2 & 0.73 & 0.67 & 0.68 & 0.49 & 0.71 & \\
\hline \multirow[t]{4}{*}{ Observations } & 49 & 49 & 50 & 50 & 49 & \\
\hline & $P A N E$ & B: First-stc & ge regressior & & & \\
\hline & $(1)$ & $(2)$ & (3) & (4) & (5a) & $(5 b)$ \\
\hline & $\begin{array}{c}\text { Dep. } \\
\text { Variable: } \\
\text { Institutional } \\
\text { Quality }\end{array}$ & $\begin{array}{c}\text { Dep. } \\
\text { Variable: } \\
\text { Political } \\
\text { Institutions }\end{array}$ & $\begin{array}{c}\text { Dep. } \\
\text { Varibale: } \\
\text { Migration } \\
\text { Institutions }\end{array}$ & $\begin{array}{c}\text { Dep. } \\
\text { Variable: } \\
\text { Migration } \\
\text { Attitudes }\end{array}$ & $\begin{array}{c}\text { Dep. } \\
\text { Variable: } \\
\text { Political } \\
\text { Institutions }\end{array}$ & $\begin{array}{c}\text { Dep. } \\
\text { Variable: } \\
\text { Migration } \\
\text { Institutions }\end{array}$ \\
\hline \multirow[t]{2}{*}{ Wage Gap } & -0.008 & 0.108 & 0.051 & -0.45 & 0.06 & -0.107 \\
\hline & {$[0.12]$} & {$[1.56]$} & {$[0.79]$} & {$[1.69]^{*}$} & {$[0.71]$} & {$[0.97]$} \\
\hline \multirow[t]{2}{*}{ Agricultural Share } & 0.008 & 0.024 & 0.017 & 0 & 0.024 & 0.018 \\
\hline & {$[0.78]$} & {$[1.41]$} & {$[0.90]$} & {$[0.01]$} & [1.31] & {$[0.89]$} \\
\hline \multirow[t]{2}{*}{ Share of Young } & 0.013 & 0.027 & 0.018 & 0.022 & 0.028 & 0.029 \\
\hline & {$[0.67]$} & {$[1.02]$} & {$[0.56]$} & {$[0.40]$} & [1.03] & {$[0.83]$} \\
\hline \multirow{2}{*}{ Agric. Sh. X Sh. of Young } & 0 & -0.001 & -0.001 & 0 & -0.001 & -0.001 \\
\hline & {$[0.81]$} & {$[1.41]$} & {$[0.96]$} & {$[0.04]$} & {$[1.32]$} & {$[1.00]$} \\
\hline \multirow[t]{2}{*}{ Political Instit. Instrument } & 0.268 & 0.594 & & & 0.628 & 0.221 \\
\hline & {$[3.36]^{* * *}$} & {$[4.98]^{* * *}$} & & & {$[5.70] * * *$} & {$[1.53]$} \\
\hline \multirow[t]{2}{*}{ Migration Instit. Instrument } & 0.41 & & 0.679 & & 0.064 & 0.78 \\
\hline & {$[8.19]^{* * *}$} & & {$[7.06]^{* * *}$} & & {$[0.66]$} & {$[8.84]^{* * *}$} \\
\hline \multirow[t]{2}{*}{ Initial Migration Attitudes } & & & & 1.705 & & \\
\hline & & & & {$[2.65]^{* *}$} & & \\
\hline \multirow[t]{2}{*}{ Constant } & -0.154 & -0.578 & -0.236 & -0.855 & -0.64 & -0.639 \\
\hline & {$[0.30]$} & {$[0.76]$} & {$[0.27]$} & {$[0.59]$} & {$[0.84]$} & {$[0.67]$} \\
\hline Adjust. R2 & 0.78 & 0.66 & 0.66 & 0.46 & 0.65 & 0.69 \\
\hline Observations & 49 & 49 & 50 & 50 & 49 & 49 \\
\hline
\end{tabular}

Robust t statistics in brackets

$*$ significant at $10 \% ; * *$ significant at $5 \% ; * * *$ significant at $1 \%$ 